\title{
A CALCULATION METHOD OF ECOSYSTEM SERVICE VALUE BASED ON PRODUCT OF NATIONAL GEOGRAPHIC CONDITIONS MONITORING IN CHINA
}

\author{
Cheng Tao ${ }^{1}$, Zheng Xinyan ${ }^{1,}{ }^{*}$,Chen Huixian ${ }^{2}$, Liu Jin ${ }^{1}$, Gao Xinyuan ${ }^{3}$, Zhang Weiwei ${ }^{4}$ \\ ${ }^{1}$ National Geomatics Center of China, 28 Lianhuachi West Road, Haidian District, Beijing, China - (chengtao, xinyan_zheng, \\ liujin)@ngcc.cn \\ ${ }^{2}$ Map Supervision Center, MNR of China, 28 Lianhuachi West Road, Haidian District, Beijing, China - 350874364@qq.com \\ ${ }^{3}$ Land Satellite Remote Sensing Application Center, MNR of China, 1 Baishengcun Zizhuyuan, Haidian District, Beijing, China - \\ 969520377@qq.com \\ ${ }^{4}$ School of Geography Science and Geomatics Engineering, Suzhou University of Science and Technology, 99 Xuefu Road, New \\ District, Suzhou, Jiangsu, China-77189592@qq.com
}

KEY WORDS: Ecosystem Service Value, Calculation Method, National Geographic Conditions Monitoring, Land cover, MODIS, EVI, NPP

\begin{abstract}
:
By 2015, Chinese government had completed the project of China's First National Geographic Conditions Census. In this project, high resolution land cover product all over the country had been generated, and would be updated continuously every year. On the basis of this excellent data source, a big data calculating method of land's ecosystem service value was proposed, in which many other remote sensing information were used too, such as EVI (Enhanced Vegetation Index), NPP (Net Primary Productivity), vegetation growing season data derived from MODIS product. It analyzed the characters of data type, data time phase, and data structure for all the remote sensing information, also the big data's engendering background and process. A revised ecosystem service value assessment model was used for calculating. Combining the classification system of terrestrial ecosystem in China and the equivalent value factor per unit ecosystem area, the big data calculating algorithm was designed. Shiyan city, Hubei province, China was selected as the study area for validating the calculating method. The results showed that the total ecosystem service value in Shiyan city in 2015 was $1.97 \times 10^{11} \mathrm{CNY}$, and the per capita ecosystem service value was $5.69 \times 10^{4} \mathrm{CNY}$. Specially, forest supplied the most ecosystem service value which accounted for $78.54 \%$, followed by water, grassland, farmland, and desert. The research shows that on the basis of multi-source of remote sensing information mainly the high resolution land cover product obtained in the project of China's First National Geographic Conditions Census, high-precision quantification and spatialization ecosystem service value can be calculated and obtained; multi scale spatial display of the calculating results could be achieved to meet different spatial scaling demands; the big data calculating algorithm has solved the problems of design and computation of structured and unstructured big data computing models; the independent research and development software has solved the problem of software requirements, and the operational efficiency and performance can meet the calculating needs.
\end{abstract}

\section{INTRODUCTION}

With the development of economics and society, the destruction of natural resources and environment is aggravated. The values of ecological environment and ecosystem service have been paid more and more attention popularly. Chinese government has integrated the construction of ecological civilization into all aspects and processes of economic construction, political construction, cultural construction and social construction, and clearly puts forward that we should establish the concept of natural value and natural capital, also natural ecosystem is valuable.

Ever since 90's of last century, after ecosystem services classification and monetary value of service value were proposed by Costanza (Costanza et al., 1997a), the evaluating principles and methods of ESV (Ecosystem Service Value) had been clarified, the proposed algorithm had also been widely used in all kinds of ESV evaluation and had gotten some research achievements. At the same time, the quantitative evaluation model of ESV has also become a research hotspot in recent years. Xie G D, et al. evaluated ESV of 11 ecological service types provided in 2010 mainly used the method of unit area ecosystem value equivalent factor, based on the principle of labor value theory, and obtained various ESV's total amount in China (Xie et al., 2015a). Jiang C H, et al. modified Costanza's model on two dimensions, which were the degree of vegetation flourishing and the effective time of vegetation providing ecological services. The ESV of Qinghai Lake basin in 2000 and 2012 were evaluated (Jiang et al., 2016a). Li G Y, et al. took Yichun for example to carry out the ESV evaluation and analyzed its relationship with the social and economic development (Li et al., 2016a).

The classification method of ecosystem service type and the value evaluation model are the basis of quantitative calculation. Costanza, et al. divided the ecosystem service into 17 types. Foreign researchers have developed InVEST (Wang et al., 2015a), CITYgreen (Chen et al., 2009a) and other ESV evaluation models, which have been utilized in biodiversity protection, resources and environment management, regional planning and other fields. The Millennium Ecosystem Assessment divided ecosystem services into 4 categories: supply services, regulation services, support services and cultural services. And a number of second level types were divided based on these categories (Millennium Ecosystem Assessment, 2003). According to China's national conditions, Xie G D, et al. subdivided 11 second level types under the first

* Corresponding author 
level. Based on the method of equivalent value per unit area, a national equivalent of the unit area's ecosystem service value was established (Xie et al., 2008a).

In the process of computing the value of ecosystem services, remote sensing information is an important data source. High resolution land cover data all over China had been produced in the project of China's First National Geographic Conditions Census based on remote sensing images better than $1 \mathrm{~m}$ spatial resolution. Besides, MODIS data has played an important role in resource, environment, and ecological aspects for its high temporal resolution and high spectral resolution.

Remarkably, big data will be generated during the national land ESV calculation process, in order to solve the problem of big data calculating efficiency and performance, a method of calculating and analyzing of ESV was proposed based on multisource of remote sensing information, mainly the high resolution land cover product generated in the project of China's First National Geographic Conditions Census, and EVI, NPP, and vegetation growing season data extracted in MODIS datasets. Evaluation model referred to the existing and be widely accepted model, study area was selected and the ESV was calculated and analyzed to verify the feasibility and applicability of the method, which could facilitate the popularization and application of the method.

\section{DATA AND STUDY AREA}

\subsection{Land Cover Resource Data}

The high resolution land cover data generated in the project of China's First National Geographic Conditions Census could reflect the natural and human geography spatial distribution. The unified time for this product was June 30, 2015. The land cover classification system defined 10 classes of level I, which were cultivated land, garden plot, forest land, grassland, building construction, road, structure, artificial stack land, bare land and water; also it defined 46 classes of level II, and 79 classes of level III (Leading Group Office of China's first National Geographic Conditions Census of the State Council, 2013). The smallest pattern corresponding to the ground field area was $400 \mathrm{~m}^{2}$.

The initial land cover product was vector spatial data, and the total pattern quantity reached hundreds of millions. For the convenience of calculation and precision guarantee of results, the vector spatial data was rasterized, and the grid size was defined as $5 \mathrm{~m} * 5 \mathrm{~m}$. In the rasterization process, the largest area of land cover type in one grid was used to determine the grid's land cover classification; the result was defined as 16 bit unsigned integer.

In the land ESV calculation process, involved in the inputting calculation of data and structure types included: rasterized land cover data, the land maximum EVI data (16 bit, signed integer), the land NPP data (32 bit, float), and the vegetation growing season data (32 bit, float). The outputting data and structure types included: supply services, regulation services, support services and cultural services of individual ESV data, and the total ESV data, which were all 32 bit float. The amount of data was in the magnitude of $10 \mathrm{~TB}$, forming a scale of big data calculation.

According to the "classification system of terrestrial ecosystems in China", the terrestrial ecosystems in China were divided into 6 classes of level I, which were farmland, forest, grassland, wetland, desert and water, also it defined 15 classes of level II. The transformation and expression relationship of classification system between China's First National Geographic Conditions Census and "classification system of terrestrial ecosystems in China" needed to be built during the calculation. Each grid would be calculated by transformed type.

\subsection{MODIS Dataset}

The standard MOD13Q1 product of MODIS dataset contains 12 sub datasets, in which the EVI dataset can accurately reflect vegetation's growing status and seasonal and interannual variations features. It has been widely used in the global and regional ecological environment monitoring and other aspects. The spatial resolution of EVI data is $250 \mathrm{~m}$.

In the process of ESV calculation, the spatial heterogeneity of the same ecosystem service, vegetation's flourishing degree and the time of vegetation provide effective ecological services should be considered. At the same time, in order to reflect the earth's surface nature state in the same period with the unified time of China's First National Geographic Conditions Census, MODIS dataset of 2015 was obtained (https://modis.gsfc.nasa.gov/) and used.

\subsection{Equivalents of per Unit Area}

The standard value equivalent of ecosystem service function is the annual average value equivalent of all kinds of ecosystem service functions on unit area of different types of ecosystems, which reflects the annual average value of different ecosystems and their ecosystem services in the whole country. Xie G D, et al. defined one standard value equivalent of ecosystem service function as the natural grain's economic value of $1 \mathrm{hm}^{2}$ average output.

When calculating, the standard value equivalent of ecosystem service function mainly quoted the modified equivalent value factor proposed by Xie $\mathrm{G} \mathrm{D}^{2}$, et al. The greenhouse ESV equivalent quoted the research results by $\mathrm{Li} \mathrm{G} \mathrm{Y}^{4}$, et al. as in Table 1. Meanwhile, the Chinese average grain yield, grain price per unit area, and the CPI (Consumer Price Index) information in 2015 were referred to. Synthetically, the economic value of ESV equivalent was determined to be 3595.22 CNY / $\mathrm{hm}^{2}$.

\begin{tabular}{|c|c|c|c|c|c|c|c|c|c|c|c|c|}
\hline \multicolumn{2}{|c|}{ ESV type } & \multicolumn{3}{|c|}{ Supply services } & \multicolumn{4}{|c|}{ Regulation services } & \multicolumn{3}{|c|}{ Support services } & \multirow{2}{*}{$\begin{array}{c}\text { Cultur } \\
\text { al } \\
\text { servic } \\
\text { es }\end{array}$} \\
\hline $\begin{array}{c}\text { Level } \\
\text { I }\end{array}$ & Level II & $\begin{array}{l}\text { Food } \\
\text { produc } \\
\text { tion }\end{array}$ & $\begin{array}{c}\text { Raw } \\
\text { materi } \\
\text { al } \\
\text { produc } \\
\text { tion }\end{array}$ & $\begin{array}{c}\text { Water } \\
\text { resour } \\
\text { ces } \\
\text { suppl } \\
\text { y } \\
\end{array}$ & $\begin{array}{l}\text { Gas } \\
\text { regula } \\
\text { tion }\end{array}$ & $\begin{array}{c}\text { Climat } \\
\text { e } \\
\text { adjust } \\
\text { ment }\end{array}$ & $\begin{array}{l}\text { Purifica } \\
\text { tion }\end{array}$ & $\begin{array}{c}\text { Environ } \\
\text { mental } \\
\text { hydrolog } \\
\text { y }\end{array}$ & $\begin{array}{c}\text { Soil } \\
\text { conserv } \\
\text { ation }\end{array}$ & $\begin{array}{l}\text { Nutri } \\
\text { ent } \\
\text { cycli } \\
\text { ng }\end{array}$ & $\begin{array}{c}\text { Biodive } \\
\text { rsity }\end{array}$ & \\
\hline Farml & Dry land & 0.85 & 0.40 & 0.02 & 0.67 & 0.36 & 0.10 & 0.27 & 1.03 & 0.12 & 0.13 & 0.06 \\
\hline
\end{tabular}




\begin{tabular}{|c|c|c|c|c|c|c|c|c|c|c|c|c|}
\hline \multirow[t]{2}{*}{ and } & $\begin{array}{l}\text { Paddy } \\
\text { field }\end{array}$ & 1.36 & 0.09 & -2.63 & 1.11 & 0.57 & 0.17 & 2.72 & 0.01 & 0.19 & 0.21 & 0.09 \\
\hline & $\begin{array}{l}\text { Greenho } \\
\text { use }\end{array}$ & 1.40 & 0.66 & 0 & 0.57 & 0.27 & 0 & 0 & 2.01 & 0.13 & 0.09 & 0.03 \\
\hline \multirow{4}{*}{ Forest } & Needle & 0.22 & 0.52 & 0.27 & 1.70 & 5.07 & 1.49 & 3.34 & 2.06 & 0.16 & 1.88 & 0.82 \\
\hline & $\begin{array}{l}\text { Conifero } \\
\text { us and } \\
\text { Broad-le } \\
\text { aved } \\
\text { mixed }\end{array}$ & 0.31 & 0.71 & 0.37 & 2.35 & 7.03 & 1.99 & 3.51 & 2.86 & 0.22 & 2.60 & 1.14 \\
\hline & $\begin{array}{l}\text { Broadlea } \\
\mathrm{f}\end{array}$ & 0.29 & 0.66 & 0.34 & 2.17 & 6.50 & 1.93 & 4.74 & 2.65 & 0.20 & 2.41 & 1.06 \\
\hline & Shrub & 0.19 & 0.43 & 0.22 & 1.41 & 4.23 & 1.28 & 3.35 & 1.72 & 0.13 & 1.57 & 0.69 \\
\hline \multirow{2}{*}{$\begin{array}{c}\text { Grassl } \\
\text { and }\end{array}$} & $\begin{array}{c}\text { Grasslan } \\
\mathrm{d}\end{array}$ & 0.10 & 0.14 & 0.08 & 0.51 & 1.34 & 0.44 & 0.98 & 0.62 & 0.05 & 0.56 & 0.25 \\
\hline & $\begin{array}{c}\text { Water } \\
\text { meadow }\end{array}$ & 0.22 & 0.33 & 0.18 & 1.14 & 3.02 & 1.00 & 2.21 & 1.39 & 0.11 & 1.27 & 0.56 \\
\hline $\begin{array}{c}\text { Wetla } \\
\text { nd }\end{array}$ & Wetland & 0.51 & 0.50 & 2.59 & 1.90 & 3.60 & 3.60 & 24.23 & 2.31 & 0.18 & 7.87 & 4.73 \\
\hline \multirow[b]{2}{*}{ Desert } & Desert & 0.01 & 0.03 & 0.02 & 0.11 & 0.10 & 0.31 & 0.21 & 0.13 & 0.01 & 0.12 & 0.05 \\
\hline & $\begin{array}{l}\text { Bare } \\
\text { land }\end{array}$ & 0.00 & 0.00 & 0.00 & 0.02 & 0.00 & 0.10 & 0.03 & 0.02 & 0.00 & 0.02 & 0.01 \\
\hline \multirow[b]{2}{*}{ Water } & Water & 0.80 & 0.23 & 8.29 & 0.77 & 2.29 & 5.55 & 102.24 & 0.93 & 0.07 & 2.55 & 1.89 \\
\hline & $\begin{array}{c}\text { Glacial } \\
\text { Snow }\end{array}$ & 0.00 & 0.00 & 2.16 & 0.18 & 0.54 & 0.16 & 7.13 & 0.00 & 0.00 & 0.01 & 0.09 \\
\hline
\end{tabular}

Table 1. The equivalents of ESV supplied by per unit area of ecosystem

\subsection{Study Area}

Shiyan city locates in the northwest of Hubei province, China between $109^{\circ} 26^{\prime}$ and $111^{\circ} 35^{\prime}$ E longitude and $31^{\circ} 30^{\prime}-33^{\circ} 16^{\prime} \mathrm{N}$ latitude. According to the administrative divisions of the People's Republic of China 2015, Shiyan city's area is $23698 \mathrm{~km}^{2}$, and the population is 3.47 million (Ministry of Civil Affairs of the People's Republic of China, 2015). Shiyan city is located in the mid latitude region, which is the subtropical monsoon climate region. With the wide distribution of river system and abundant rainfall, the water resource is very abundant. It is one of the best ecological protection cities in China. Danjiangkou reservoir, which is the Middle Route Project of South to North Water Diversion in China, is located in Shiyan city.

8 districts and counties locate in Shiyan city, which are Maojian district, Zhangwan district, Yunyang district, Danjiangkou city, Yunxi county, Zhushan county, Zhuxi county, and Fang county, as shown in Figure 1. Because some districts and counties involve enclave regions, in order to facilitate data processing and statistical analysis, the enclave regions were adjusted, including the enclaves between districts and counties in Shiyan city, and the enclaves between Shiyan city and other province or cities. Specific adjustment methods are shown in Table 2.

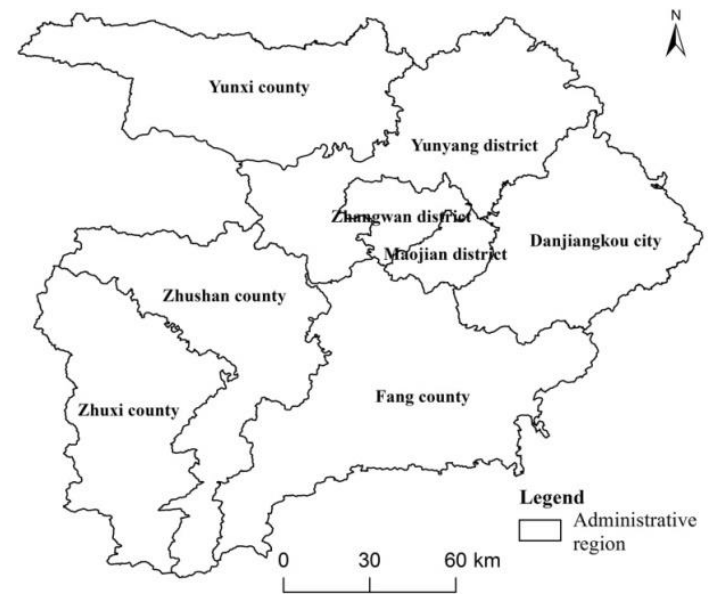

Figure 1. The study area

\begin{tabular}{|c|c|c|c|}
\hline Enclave type & Enclave caption & Zone code & Adjustment method \\
\hline \multirow{2}{*}{$\begin{array}{l}\text { The enclaves between } \\
\text { districts and counties in } \\
\text { Shiyan city }\end{array}$} & $\begin{array}{l}\text { Two enclaves in Zhushan county, but belong to Zhuxi } \\
\text { county }\end{array}$ & 420324 & $\begin{array}{l}\text { Merged to Zhushan } \\
\text { county }\end{array}$ \\
\hline & $\begin{array}{l}\text { One enclave in Fang county, but belongs to Zhushan } \\
\text { county }\end{array}$ & 420323 & Merged to Fang county \\
\hline \multirow{4}{*}{$\begin{array}{l}\text { The enclaves between } \\
\text { Shiyan city and other } \\
\text { province or cities }\end{array}$} & $\begin{array}{l}\text { One enclave outside Fang county, but belongs to Fang } \\
\text { county }\end{array}$ & 420325 & Delete \\
\hline & $\begin{array}{l}\text { One enclave in Fang county, but belongs to Baokang } \\
\text { county, Xiangyang City }\end{array}$ & 420620 & Merged to Fang county \\
\hline & $\begin{array}{l}\text { One enclave outside Zhushan county, but belongs to } \\
\text { Zhushan county }\end{array}$ & 420323 & Delete \\
\hline & $\begin{array}{l}\text { One enclave in Yunyang district, but belongs to Xichuan } \\
\text { county, Henan province }\end{array}$ & 411326 & $\begin{array}{l}\text { Merged to Yunyang } \\
\text { district }\end{array}$ \\
\hline
\end{tabular}

Table 2. Adjustment method of enclaves in the study area 


\section{ALGORITHM DESIGN}

\subsection{Evaluation Model of ESV}

According to previous studies, the transformation formula of classification system between China's First National Geographic Conditions Census and "classification system of terrestrial ecosystems in China" was built to determine the ecological system type of every grid in land cover raster data. On the basis of multi-source remote sensing information and equivalents of ESV supplied by per unit area of ecosystem, the 4 individual ESV of supply services, regulation services, support services and cultural services for every grid were calculated; also the total ESV was calculated. The formulas for calculating the ESV of every grid were as follows.

The formula for calculating the total ESV of every grid:

$$
V_{i}=V_{i g}+V_{i t}+V_{i z}+V_{i w}
$$

For the specific land cover types of farmland, forest and grassland, the modified formulas were as follows.

$$
\begin{aligned}
V_{i g} & =S_{i} \times m_{-} G \times H_{n} \times \frac{m_{-} N P P_{i}}{m_{-} N P P^{\prime}} \\
V_{i t} & =S_{i} \times m_{-} T \times H_{n} \times \frac{m_{-} G S_{i}}{m_{-} G S^{\prime}} \times \frac{m_{-} E V I_{i}}{m_{-} E V I^{\prime}} \\
V_{i z} & =S_{i} \times m_{-} Z \times H_{n} \times \frac{\frac{m_{-} E V I_{i}}{m_{-} E V I^{\prime}}}{V_{i w}}=S_{i} \times m_{-} W \times H_{n} \times \frac{m_{-} G S_{i}}{m_{-} G S^{\prime}}
\end{aligned}
$$

In the formulas, $V_{i}$ stands for the total ESV of grid $i ; V_{i g}, V_{i t}$, $V_{i z}, V_{i w}$ stand for the supply service value, regulation service value, support service value and cultural service value respectively; $S_{i}$ stands for the grid's area; $m_{-} G, m_{-} T, m_{-} Z$, $m_{-} W$ stand for the equivalents of supply service value, regulation service value, support service value and cultural service value respectively; $H_{n}$ stands for the economic value of the equivalents of ESV supplied by per unit area of ecosystem; $m_{-} N P P_{i}$ stands for the $N P P$ of the specific land cover types of farmland, forest and grassland; $m_{-} N P P^{\prime}$ stands for the average $N P P$ of the specific land cover types of farmland, forest and grassland; $m_{-} E V I_{i}$ stands for the $E V I$ of the specific land cover types of farmland, forest and grassland; $m_{-} E V I^{\prime}$ stands for the average $E V I$ of the specific land cover types of farmland, forest and grassland; $m_{-} G S_{i}$ stands for the vegetation growing season of the specific land cover types of farmland, forest and grassland; $m_{-} G S^{\prime}$ stands for the average vegetation growing season of the specific land cover types of farmland, forest and grassland.
The purpose of leading EVI, NPP and vegetation growing season data into calculation was to modify the ESV to reflect the spatial heterogeneity of the same ecosystem service more accurately.

\subsection{Computing Model of Big Data}

According to the data type, data structure, data quantity and raster data quantification depth analysis, big data would be formed during the calculation. So, computing model of ESV big data needed to be designed to ensure that: (1) the big data's inputting and reading are correct; (2) the computing memory doesn't overflow; (3) the calculated results of 4 individual ESV and the total ESV can be output simultaneously for same calculation unit; (4) the batch process is normally.

At present, commercial software is difficult to meet the computing demand, mainly in: (1) data's inputting capacity is limited at the software's inputting interface, only a small amount of data could be input in a single inputting; (2) the calculation process is not easy to realize batch processing mode (3) the calculated results of 4 individual ESV and the total ESV cannot be output simultaneously for same calculation unit. These problems lead to the enormous workload of data preprocessing and data calculation, which greatly affects the efficiency of the data production of the final results.

In view of this situation, ESV assessment software was developed based on the theory of raster spatial analysis, which realized the functions of organization structure, function distribution, data interface ( $\mathrm{Li}, 2014)$, operation and error handling, and so on. This software had solved the technical problems of the land ESV calculation process, improved the level of data processing, and improved the data calculation speed, efficiency and quality.

Computing model of big data had solved the technical problems in three aspects: (1) at the condition of a single data volume is large, the computing model distributes reasonable computing memory to ensure the computing performance; (2) the inputting data and outputting data's volume are both very huge, the computing model realizes batch processing to improve computing efficiency; (3) the computing model solves the problem of integrated inputting and simultaneous outputting for the multi-source data in same calculation unit, so as to improve the efficiency of data computation. So, the computing model is as Figure 2 . 


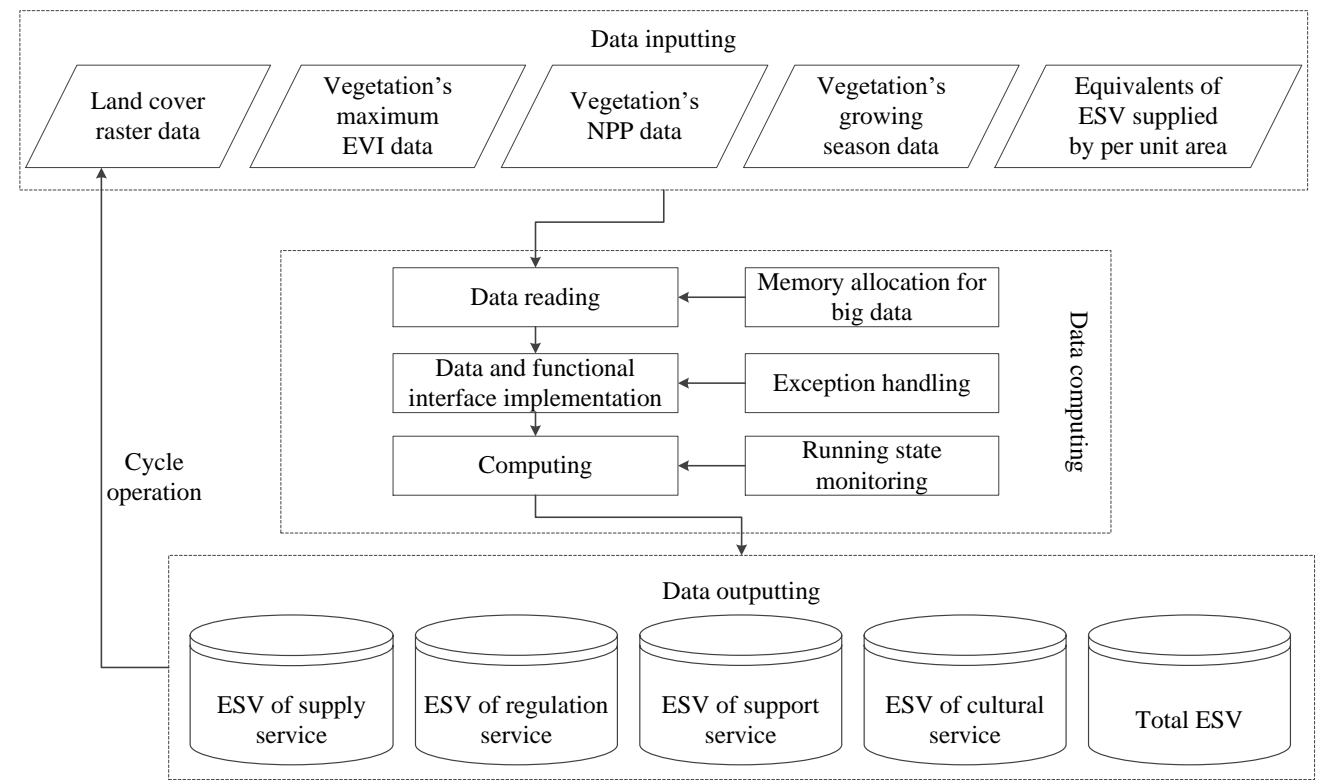

Figure 2. Model design of ESV big data calculating

\section{RESULTS AND ANALYSIS}

\subsection{EVI, NPP and Growing Season Patterns}

The vegetation's maximum EVI, NPP and growing season spatial pattern in the study area in 2015 are shown in Figure 3. From Figure 3, the maximum EVI value in the study area in

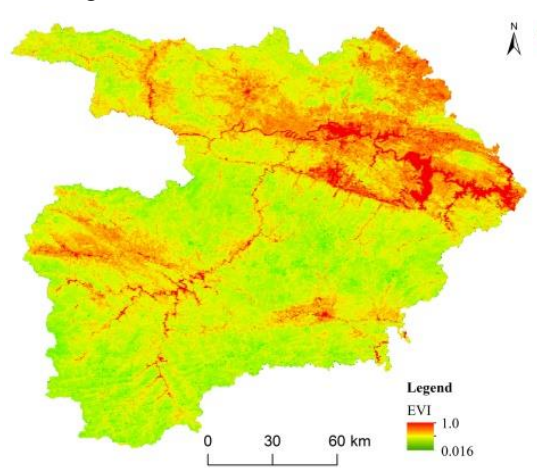

(a) Spatial pattern of EVI

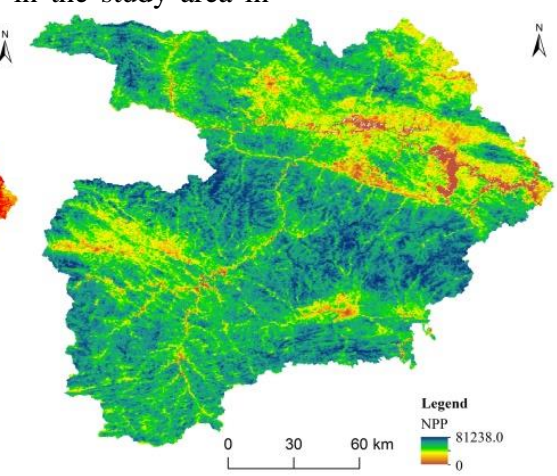

(b) Spatial pattern of NPP
2015 was at a high level, the maximum NPP value reached 81238.0 g.C $/ \mathrm{m}^{2}$, and the value range of vegetation growing season was from 16 to 365 . The data showed that the vegetation's growing conditions were good, the development was very luxuriant, and the growing season was long.

Figure 3. Spatial patterns of vegetation's EVI, NPP and growing season during 2015

\subsection{ESV and Its Spatial Patterns}

(1) In the study area, the total number of land cover patches reached 1,181,000. The rasterization processing was carried out on classification code attribute. And the rasterization results of
$5 \mathrm{~m} * 5 \mathrm{~m}$ granularity were obtained. The evaluation model of ESV was used to calculate. The ESV result's spatial pattern is shown in Figure 4.

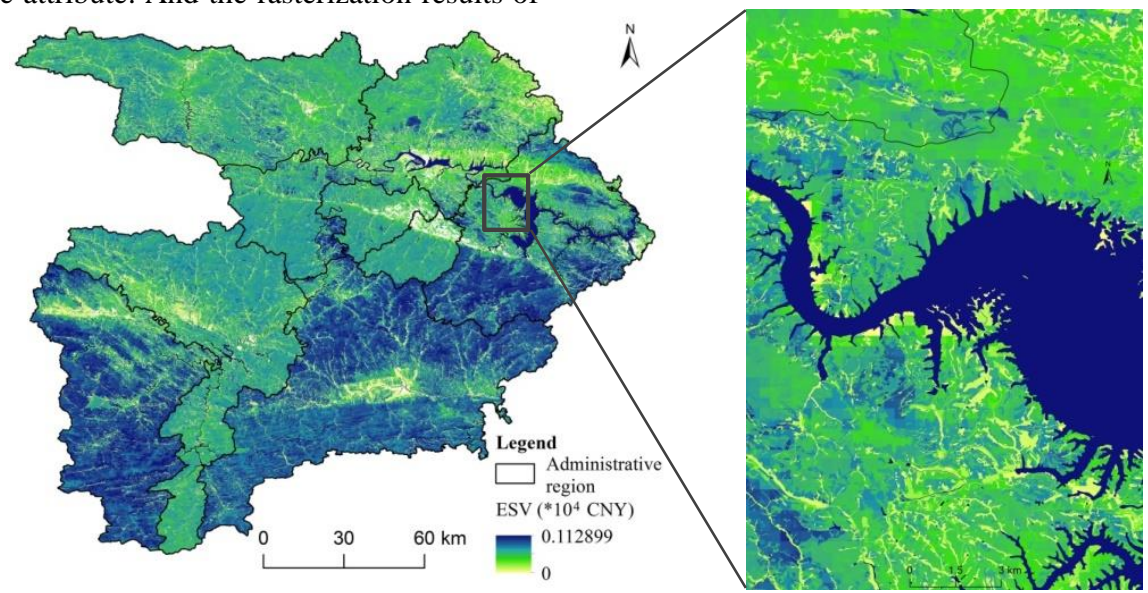

Figure 4. Spatial patterns of ESV and its local enlargement ( $5 \mathrm{~m} * 5 \mathrm{~m}$ grid granularity) 
The statistical analysis results included total ESV, supply service value, regulation service value, support service value and cultural service value respectively, and ESV of 6 classes of terrestrial ecosystems, as shown in Table 3.

\begin{tabular}{|c|c|c|c|c|c|c|c|c|c|}
\hline $\begin{array}{c}\text { Administrative } \\
\text { division }\end{array}$ & $\begin{array}{c}\text { Population } \\
\left(\times 10^{4}\right)\end{array}$ & $\begin{array}{c}\text { Area } \\
\left(\mathrm{km}^{2}\right)\end{array}$ & $\begin{array}{c}\text { Total } \\
\text { ESV } \\
\left(\times 10^{8}\right. \\
\mathrm{CNY})\end{array}$ & $\begin{array}{c}\text { Per capita } \\
\text { ESV } \\
\left(\times 10^{4}\right. \\
\mathrm{CNY})\end{array}$ & $\begin{array}{c}\text { ESV of } \\
\text { unit area } \\
\left(\times 10^{4}\right. \\
\mathrm{CNY} \\
\left./ \mathrm{hm}^{2}\right)\end{array}$ & $\begin{array}{c}\text { ESV of } \\
\text { supply } \\
\text { service } \\
\left(\times 10^{8}\right. \\
\mathrm{CNY})\end{array}$ & $\begin{array}{c}\text { ESV of } \\
\text { regulation } \\
\text { service } \\
\left(\times 10^{8}\right. \\
\mathrm{CNY})\end{array}$ & $\begin{array}{c}\text { ESV of } \\
\text { support } \\
\text { service } \\
\left(\times 10^{8}\right. \\
\mathrm{CNY})\end{array}$ & $\begin{array}{c}\text { ESV of } \\
\text { cultural } \\
\text { service } \\
\left(\times 10^{8}\right. \\
\mathrm{CNY})\end{array}$ \\
\hline Maojian district & 28 & 578 & 34.84 & 1.24 & 6.03 & 2.52 & 24.40 & 6.59 & 1.33 \\
\hline Zhangwan district & 26 & 652 & 44.25 & 1.70 & 6.79 & 3.17 & 31.48 & 7.85 & 1.75 \\
\hline Yunyang district & 62 & 3863 & 281.02 & 4.53 & 7.27 & 21.42 & 203.80 & 45.44 & 10.37 \\
\hline Danjiangkou city & 46 & 3121 & 350.49 & 7.62 & 11.23 & 24.63 & 269.39 & 44.31 & 12.16 \\
\hline Yunxi county & 52 & 3509 & 237.29 & 4.56 & 6.76 & 18.55 & 166.01 & 43.93 & 8.79 \\
\hline Zhushan county & 47 & 3586 & 259.83 & 5.53 & 7.25 & 19.31 & 185.37 & 46.21 & 8.94 \\
\hline Zhuxi county & 37 & 3279 & 305.75 & 8.26 & 9.32 & 20.27 & 214.18 & 58.56 & 12.74 \\
\hline Fang county & 49 & 5110 & 459.73 & 9.38 & 9.00 & 31.70 & 321.42 & 87.94 & 18.67 \\
\hline Shiyan city & 347 & 23698 & 1973.20 & 5.69 & 8.33 & 141.57 & 1416.05 & 340.85 & 74.74 \\
\hline
\end{tabular}

Table 3. Statistical analysis results of ESV

(2) According to Figure 4, from the view of region, the ESV in the east, west and south were higher than that in the north. According to Table 3, the total ESV value in Shiyan in 2015 was $1.97 \times 10^{11} \mathrm{CNY}$, and the ESV value of unit area was $8.33 \times 10^{4} \mathrm{CNY} / \mathrm{hm}^{2}$. In the 8 county-level administrative divisions, Danjiangkou city's ESV of unit area was the highest, reached $1.12 \times 10^{5} \mathrm{CNY} / \mathrm{hm}^{2}$, and the lowest area was Maojian district, only $6.03 \times 10^{4} \mathrm{CNY} / \mathrm{hm}^{2}$.

From the view of terrestrial ecosystems types, forest ESV was the highest, reached $1.55 \times 10^{11} \mathrm{CNY}$, accounted for $78.54 \%$ of the total ESV; followed by water ESV of $2.67 \times 10^{10} \mathrm{CNY}$. The individual ESV took on the sequential characteristics of forest, water, grassland, farmland and desert.

From the view of ecosystem service types, regulation service value was the highest, reached $1.42 \times 10^{11} \mathrm{CNY}$, accounted for $71.76 \%$ of the total ESV; followed by support service value of $17.27 \%$ of the total ESV. The individual ESV took on the sequential characteristics of regulation service value, support service value, supply service value and cultural service value. in Shiyan city was $5.69 \times 10^{4} \mathrm{CNY}$; according to the statistical yearbook data of 2015 , the GDP was $1.30 \times 10^{11} \mathrm{CNY}$ in 2015 , and per capita GDP was $3.84 \times 10^{4} \mathrm{CNY}$ (http://www.shiyan.gov.cn/xwzx_2477/syyw_2479/201604/t20 160405_324961.shtml). The ratio of per capita GDP and per capita ESV was 1:1.48. The results showed that the value of ecosystem services in the study area was relative richer than the social and economic value, which indicated that the local government was also paying attention to the protection of the ecological environment while developing the social economy.

\subsection{Multi Scale Spatial Effect of ESV}

Different granularity ESV results can reflect different ESV spatial patterns from microscopic to macroscopic. In different spatial scales, the appropriate granularity ESV results could enhance the visual expression effect.

Therefore, in order to adapt to the spatial expression of ESV at different spatial scales, based on the initial $5 \mathrm{~m} * 5 \mathrm{~m}$ grid, the $100 \mathrm{~m} * 100 \mathrm{~m}, 200 \mathrm{~m} * 200 \mathrm{~m}, 500 \mathrm{~m} * 500 \mathrm{~m}$ and $1000 \mathrm{~m} * 1000 \mathrm{~m}$ granularity ESV results were generated respectively, as shown in Figure 5 .

(3) According to Table 3, in 2015 the per capita amount of ESV

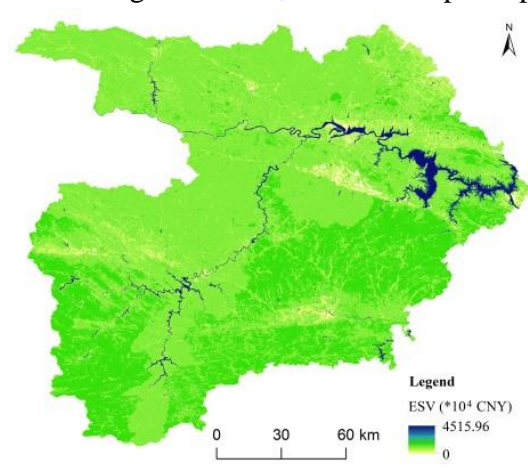

(a) $100 \mathrm{~m} * 100 \mathrm{~m}$

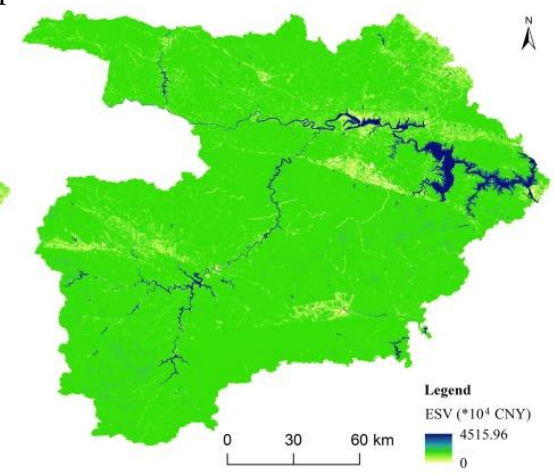

(b) $200 \mathrm{~m} * 200 \mathrm{~m}$

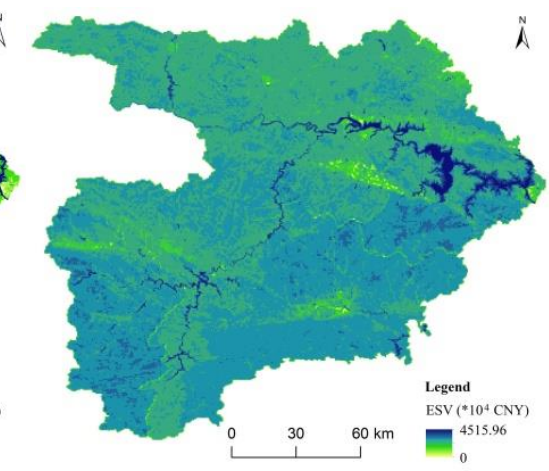

(c) $500 \mathrm{~m} * 500 \mathrm{~m}$ 


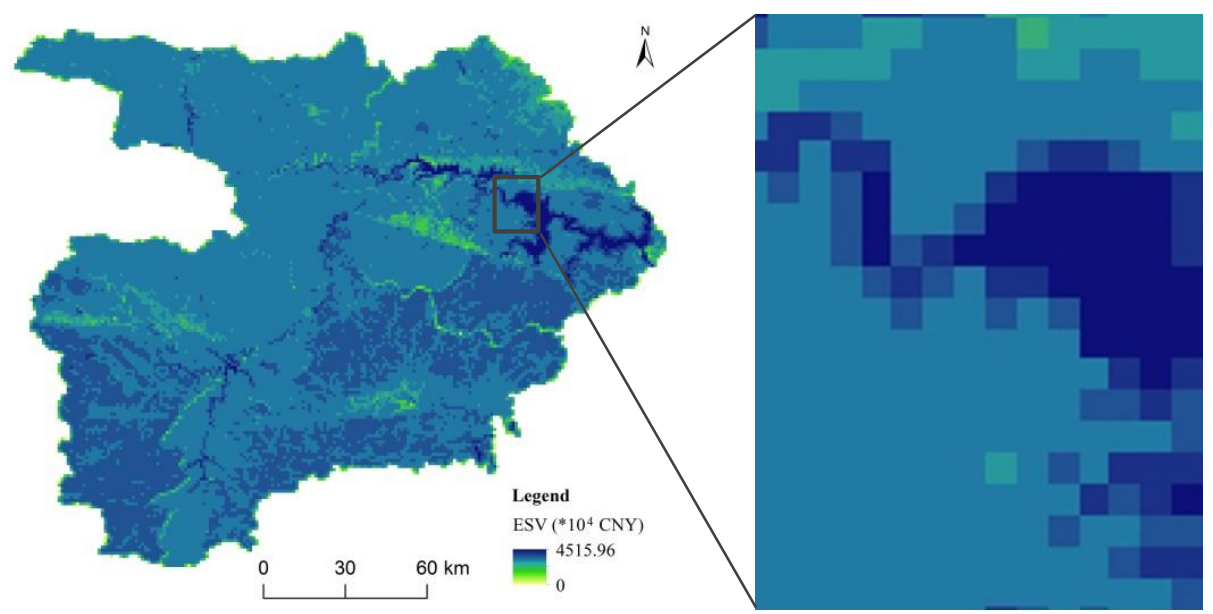

(d) $1000 \mathrm{~m} * 1000 \mathrm{~m}$ and its local enlargement

Figure 5. Comparisons of multi scale spatial displays

By comparing the local enlargements of Figure 5 (d) with Figure 4, it was easy to see the effect of different grid granularity in the same scale space, and this scale effect could meet the needs of different management scales.

\subsection{Calculation Efficiency and Performance}

For big data computing, the acceptable processing efficiency is important for a reasonable and scientific computing algorithm. Only when the processing efficiency reaches a certain level, the computation results can be obtained in finite time. The problems of data operation efficiency and computing performance were solved by using block algorithm for single big data and batching cycle processing algorithm for the whole big data.

Table 4 shows the data computing efficiency of single computer and single thread (computer system is Windows 7, 64 bit operation system, $32 \mathrm{~GB}$ memory, $1.9 \mathrm{GHz}$ processor).

\begin{tabular}{|c|c|c|c|c|}
\hline $\begin{array}{c}\text { Scope } \\
\text { of data } \\
\left(\mathrm{km}^{2}\right)\end{array}$ & $\begin{array}{c}\text { Inputting } \\
\text { data } \\
\text { quantity } \\
(\mathrm{GB})\end{array}$ & $\begin{array}{c}\text { Outputting } \\
\text { data } \\
\text { quantity } \\
(\mathrm{GB})\end{array}$ & $\begin{array}{c}\text { Calculation } \\
\text { time } \\
\text { (minute) }\end{array}$ & $\begin{array}{c}\text { Memory } \\
\text { occupancy } \\
\text { (MB) }\end{array}$ \\
\hline 23698 & 10.4 & 36.6 & 55 & 260 \\
\hline
\end{tabular}

Table 4. Efficiency and capability of the method

According to Table 4, the national terrestrial ESV could be calculated in about 8 days by using single computer and single thread. If 4 computers and multi-thread are used for computing, the computation could be finished in 1 day, which could meet the computing needs.

\section{CONCLUSIONS}

Multi-source remote sensing information is used to calculate ESV is beneficial for mining and revealing the earth's natural value. The land cover data generated in the project of China's First National Geographic Conditions Census has the characteristics of high spatial resolution and high precision; MODIS data has the characteristics of high temporal resolution and high spectral resolution. It made full use of the advantages of these data through spatial analysis and statistics, which can reflect the regional features more accurately.

The ESV assessment model and the equivalents of ESV supplied by per unit area of ecosystem proposed by Xie G D and $\mathrm{Li} \mathrm{G} \mathrm{Y}$, et al. has reflected the differentiation characteristics of different ecological regions, which is very appropriate for ESV quantification and spatial expression. In different spatial scale environment such as township, county, city, province and state, appropriate grid granularity is very necessary. The proposed method can generate ESV of different granularity to meet the multi-scale spatial expression demands.

The data quantity of land ESV in China had reached $10 \mathrm{~TB}$ on the condition that the rasterization granularity more accurate than $5 \mathrm{~m} * 5 \mathrm{~m}$. The data types included images, documents, geographic information and other structured and unstructured data; the various types of ESV were calculated on every grid. The problems of data operation efficiency had been solved by using block algorithm and batching cycle processing algorithm. This all reflected the basic features of the 4 "V" of big data Volume, Variety, Value and Velocity.

With the development of China's National Geographic Conditions Monitoring, the information of national geographic conditions will continue to be updated. Meanwhile, the land vegetation's EVI, land NPP and growing season will also change with time. Therefore, the proposed method has wide application prospects. It can be applied not only on ESV assessment, but also on ESV updating and change monitoring, which has good practical application value.

\section{ACKNOWLEDGEMENTS}

This work was supported by Chinese major national project of National Geographic Conditions Monitoring (21-30-01-5).

\section{REFERENCES}

Chen L., Li P. W., Li G. C., et al., 2009a. Application of CITYGREEN model in air purification, carbon fixation and oxygen release by greenbelt system of Shenzhen City. Acta Ecologica Sinica, 29(1), pp. 272-282.

Costanza R., D'Arge R., Groot R. D., et al., 1997a. The value of the world's ecosystem services and natural capital. Nature, 387(5), pp. 253-260

Leading Group Office of China's first National Geographic Conditions Census of the State Council, 2013. Contents and 
Indexes of National Geographic Conditions Census. Surveying and Mapping Press, Beijing, China, pp. 1-49.

Jiang C. H., Li G. Y., Cheng T., et al., 2016a. Spatial-temporal pattern variation and impact factors of ecosystem service value in the Qinghai Lake Watershed. Resources Science, 38(8), pp. $1572-1584$

Li G. Y., Jiang C. H., Cheng T., et al., 2016a. Ecosystem Services Evaluation Based on National Geographical State Monitoring Land Cover Data: Take Yichun for Example. Ecological Economy, 32(10), pp. 126-129+178.

Li M. L., 2014. GDAL Source Codes Analysis and Development Guide. Posts \& Telecom Press, Beijing, China, pp. 31-34.

Millennium Ecosystem Assessment, 2003. Ecosystems and human well-being: A framework for assessment. Island Press, Washington, DC.

Ministry of Civil Affairs of the People's Republic of China, 2015. The Brochure of Administrative Divisions in P. R. China 2015. Sinomap press, Beijing, China, pp. 1-8.

Wang Y., Meng J. J., Qi Y., et al., 2015a. Review of ecosystem management based on the InVEST model. Chinese Journal of Ecology, 34(12), pp. 3526-3532.

Xie G. D., Zhang C. X., Zhang C. S., et al., 2015a. The value of ecosystem services in China. Resources Science, 37(9), pp. 1740-1746.

Xie G. D., Zhen L., Lu C. X., et al., 2008a. Expert knowledge based valuation method of ecosystem services in China. Journal of Natural Resources, 23(5), pp. 911-919. 